Farlenkov A. S., Anan'ev M. V. Ural Federal University, 19 Mira street, 620002 Ekaterinburg Fax: +7(343) 375-97-78; Phone: +7(343) 375-44-72; E-mail: rector@urfu.ru Institute of High-Temperature Electrochemistry UBRAS, 20 Akademicheskaya street, 620990 Ekaterinburg Fax: +7(343) 374-59-92; Phone: +7(343) 374-50-89; E-mail:Dir@ihte.uran.ru

\title{
Modeling of a microstructure and calculation a tortuosity factor for cathodic materials of LSM-YSZ*
}

In this work changes in physico-chemical properties (oxygen interphase exchange rate and specific resistance) and microstructure parameters (TPB length and tortuosity factor) with time have been analyzed to find the quantitative relationships on the example of composite cathode material LSM-YSZ. 3D microstructure of LSM-YSZ materials has been reconstructed and tortuosity factor has been calculated on the basis of SEM image analysis using the original software.

\footnotetext{
*This work was done under financial support from RFBR grant № 12-03-31847 / 12 and the Federal

Program № 2012-1.3.1-12-000-2006-004, number 8713.
}

(C) Farlenkov A. S., Anan'ev M. V., 2015

\section{Introduction}

One of the most important areas of the global energy and energy efficiency is the development and study of the solid oxide fuel cells (SOFCs), they belong to class of chemical power sources, in which the chemical energy reagents (fuel and oxidizer) electrochemically converted into electricity. Oxygen from the air is usually in the role of oxidizer and hydrogen as fuel. SOFC retains the ability to generate electricity as long as reagents come from the outside and the results of their interaction are taken away. A signifi- cant advantage of the SOFCs is its silent operation and a lack of emissions during its operation, but there are several problems associated with the degradation of the materials that make up SOFCs. It is known that the microstructure of functional materials is a determining factor in the kinetics of the processes occurring during operation of the SOFC. The source of the information about it is the images obtained by scanning electron microscopy (SEM). To estimate the parameters of the microstructure, analysis of two- 
dimensional micrographs of sections or the surface of the material is not enough. There are a number of parameters of the microstructure, which can only be calculated from the three-dimensional model: the length of the three-phase (TFG) and interphase (FIG) boundaries; proportion of active TFG, open pores; tortuosity factor, etc. In this paper we present the main directions and results in the analy-

\section{Results and Discussion}

The isotopic exchange of oxygen and microstructure of LSM-YSZ.

In this paper, tests of two symmetrical cells were carried out at $\mathrm{T}=850^{\circ} \mathrm{C}$, $\mathrm{PO}_{2}=10^{-2} \mathrm{~atm}$. First symmetrical cell was tested for 300 hours, and the other - for 1000 hours. During long-term tests by isotopic exchange of oxygen [1] the kinetics of the interaction of gas-phase oxygen with the test symmetric cells was studied. The parameters of the microstructure of the samples before and after the test was determined by the digital processing of photomicrographs of cross-sections obtained with the scanning electron microscope Tescan MIRA 3 LMU. Fig. 1 and Fig. 2 show photomicrographs of the cell structure of symmetric LSM-YSZ | YSZ | LSM-YSZ (La0,8Sr0,2MnO3-0,82ZrO2 . $0,08 \mathrm{Y} 2 \mathrm{O} 3$ ) before the test.

Since the contrast between the phases of LSM and YSZ in the image is absent (Fig. 2), image analysis method was used [2], in which it was established that the distribution function of particles sizes is different, and these changes are due to coarsening of the phase LSM (Fig. 3). Conducted by 3D-reconstruction of the microstructure of the electrode symmetric cells (Fig. 4), the dependence of TFG (contact between the LSM | YSZ sis of microstructure parameters on the example of the composite LSM-YSZ, and comparison of time changes in the physicochemical properties of this material (the rate of the interfacial exchange of oxygen and resistivity) and the parameters of its microstructure (TFG length and tortuosity factor) in order to find quantitative relationships.

O2) from time was obtained. The TFG length was defined as referred to the volume number of connections between voxels $($ Voxel $=$ volume pixel) of three types, corresponding to the phases LSM, YSZ and pores [4, 5]. It was established that the length of TFG decreased by approximately $15 \%$ (Fig. 5), whereas the constant of interfacial oxygen exchange $\mathbf{k}$ decreased by about $16 \%$ after 1000 hours (Fig. 6).

Apparently, the process of interfacial oxygen exchange by TFG is sufficiently fast compared with the exchange of oxygen on individual components LSM and YSZ. As a result, a decrease in TFG lenght eventually leads to a reduction of interfacial oxygen exchange constant of the composite cathode material LSM-YSZ [7].

Conductivity and tortuosity factor of composite materials LSM-YSZ.

Tortuosity factor is statistically calculated by modeling the process of random walk of particles by Monte Carlo method. $\mathrm{N}$ number of stray particles is generated in the required volume. In one step of the program, each particle performs $n$ walks with a given length L. After wandering the amount of mean-square displacements of all particles of a given ensemble is cal- 


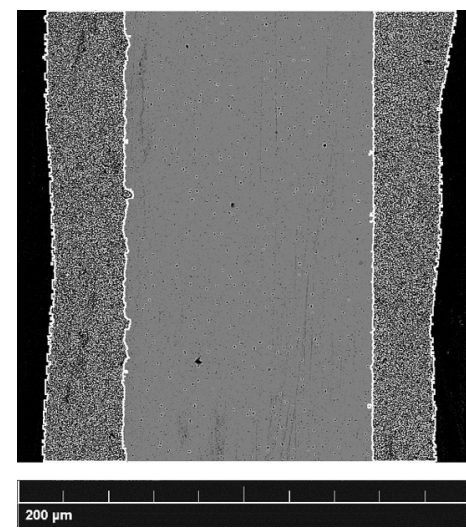

Fig. 1. Photomicrographs of the cell LSM-YSZ | YSZ | LSM-YSZ, electrolyte thickness is $140 \pm 5 \mu \mathrm{m}$, electrode $-41 \pm 10$ $\mu \mathrm{m}$

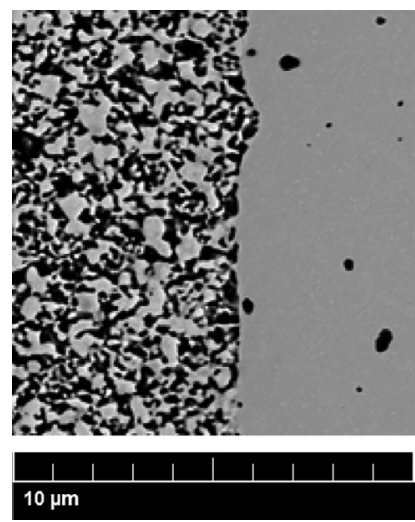

Fig. 2 Photomicrographs of the cell LSMYSZ | YSZ | LSM-YSZ

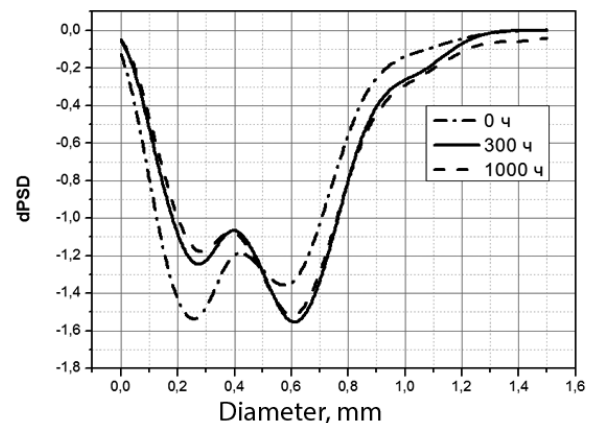

Fig. 3 Differential forms of distribution function of particles' sizes

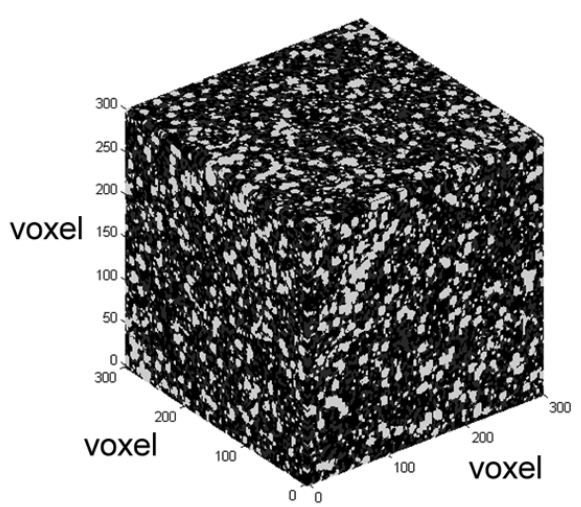

Fig. 4. 3D-reconstruction of microstructure LSM-YSZ, grey - YSZ, white - LSM, black - pores; $1 \mu \mathrm{m}=20$ voxels

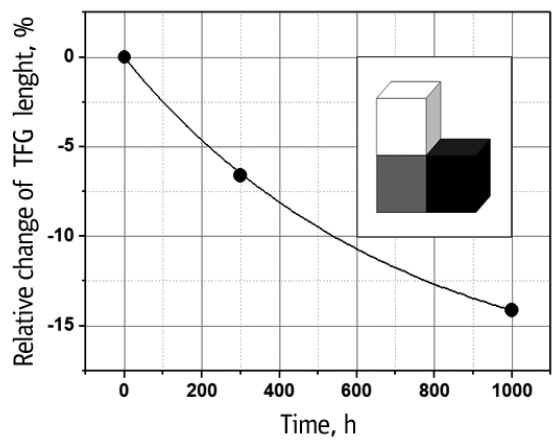

Fig. 5. The dependence of relative change of TGF length from time

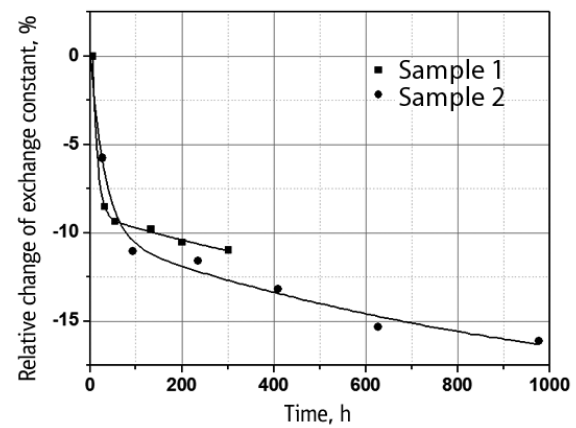

Fig. 6. The dependence of relative change of exchange constant from time $T=850{ }^{\circ} \mathrm{C}, \mathrm{Po}_{2}=10^{-2} \mathrm{~atm}$ 
culated (1). This procedure is repeated a required number of times [3]. Tortuosity factor is defined as the ratio of the mean square displacement of the particle in free space to the mean square displacement of the particles in a porous medium (2), see. Fig. 7.

$$
\begin{gathered}
<r_{t}^{2}>=\frac{1}{n} \cdot \sum_{i=1}^{n}\left(\left\{x_{i}-x_{i}^{0}\right\}^{2}+\right. \\
\left.+\left\{y_{i}-y_{i}^{0}\right\}^{2}+\left\{z_{i}-z_{i}^{0}\right\}\right), \\
<\tau_{\varphi}>=\frac{\left\langle r_{t}^{2}>_{\text {free }}\right.}{\left\langle r_{t}^{2}>_{\text {pore }}\right.}
\end{gathered}
$$

It should also be noted that the magnitude of the tortuosity factor is different from the tortuosity defined as the ratio of the average pore length to the thickness of the porous material. Unlike integral microstructure characteristics, such as porosity, the proportion of the phases and their average diameter, tortuosity factor value, depending on the environment for which it is considered to be proportional to the physico-chemical quantities. In the case of pores, tortuosity factor is proportional to the coefficient of permeability; for oxygen-ion electrolyte - the diffusion coefficient (ionic conductivity); for electronic conductor - the conductivity of the material [5]. For example, the dependence of the diffusion coefficient and the mean-square of displacement from the time is described by the expression (3).

$$
D=\frac{1}{6} \cdot \frac{d}{d t}\left\langle r_{t}^{2}\right\rangle
$$

In this part of present work it is shown that the resistivity is reduced by one order of magnitute in the example of the composite material $\mathrm{La} 0,6 \mathrm{Sr} 0,4 \mathrm{MnO}_{3}-0,9 \mathrm{ZrO}_{2}$ $\cdot 0,1 \mathrm{Y}_{2} \mathrm{O}_{3}$ shown that for 1000 hours at $\mathrm{T}$ $=800{ }^{\circ} \mathrm{C}, \mathrm{PO}_{2}=10_{-2}$ atm (fig. 10). During the tests, the samples were taken after 40 , 500 and 1000 hours of exposure.

On the basis of segmentation results of SEM images (Fig. 8) for the cross sections of the samples before and after testing using the developed original software, the tortuosity factors are calculated for both the porous structure and the phases of LSM and YSZ (Fig. 9).

A decrease in tortuosity factors phase LSM and YSZ was discovered; it correlates with the drop in resistivity of the test composite material (Fig. 9, 10). The monotonic dependence could not be found for the porous structure. Image analysis showed that as a result of the exposure diffusive propagation of LSM and YSZ phases occurs, which leads to the enlargement of particles at constant linear dimensions of the sample. Process of diffusion growth of YSZ phase goes faster than that of LSM, apparently due to the fact that YSZ was initially taken in the form of nanopowder (Fig. 8). Formation of more coherent phase structure comprised in the composite material is the cause of resistivity (Fig. 10).

Prolonged exposure under experimental conditions leads to improved contact between the grains of the components that make up the composite. Quantitative parameter characterizing the process of diffusive propagation of LSM and YSZ phase is the tortuosity factor.

\section{Conclusions}

3D-reconstruction of the microstructure based on the analysis and SEM imaging was carried out, lengths of TFG and FIG were calculated, proportion of active TFG and open pores was found in this work. 
Forsymmetric cells( $\mathrm{La} 0,8 \mathrm{Sr} 0,2 \mathrm{MnO} 3-$ $0,82 \mathrm{ZrO} 2 \cdot 0,08 \mathrm{Y} 2 \mathrm{O} 3)$ the relation-

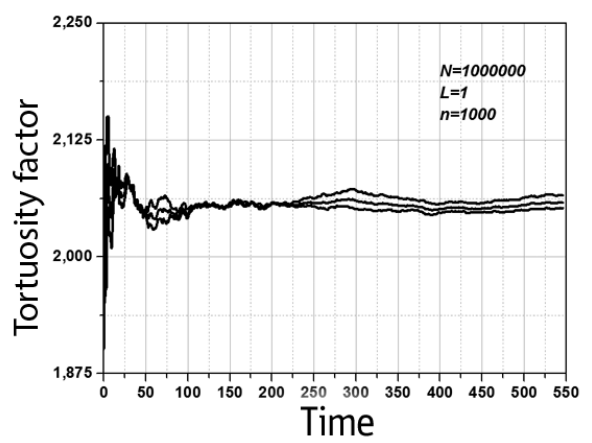

Fig. 7. Evolution of tortuosity factor data in dependence from algorithm steps

LSM-YSZ before tests

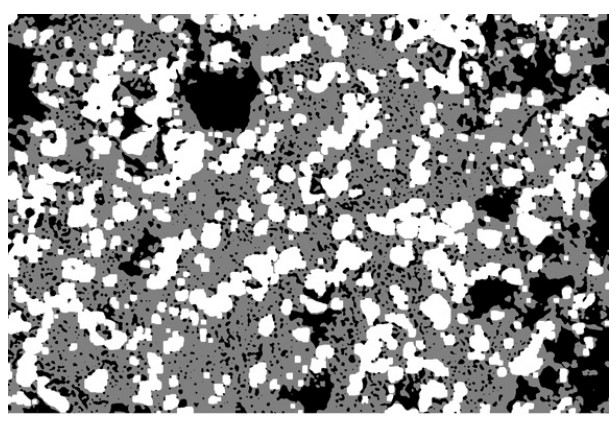

$5 \mu \mathrm{m}$

LSM-YSZ after 1000 hours exposure with $T=800{ }^{\circ} \mathrm{C}$ and $\mathrm{PO}_{2}=10^{-2} \mathrm{~atm}$

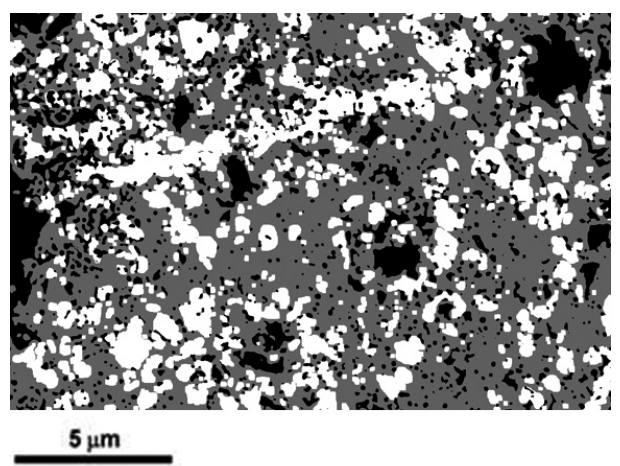

Fig 8 . The result of micrographs processing of the cross-section of the composite material LSM-YSZ, SEM (Grey - YSZ, white LSM, black - pores) ship between the constant interfacial exchange of oxygen and length TFG was obtained. For a composite material ( $\mathrm{La} 0,6 \mathrm{Sr} 0,4 \mathrm{MnO} 3-0,9 \mathrm{ZrO} 2 \cdot 0,1 \mathrm{Y} 2 \mathrm{O} 3)$ a correlation between the tortuosity factors of LSM and YSZ phases and their resistivity was found.

The approach used in this study may be useful in the study of electrochemical

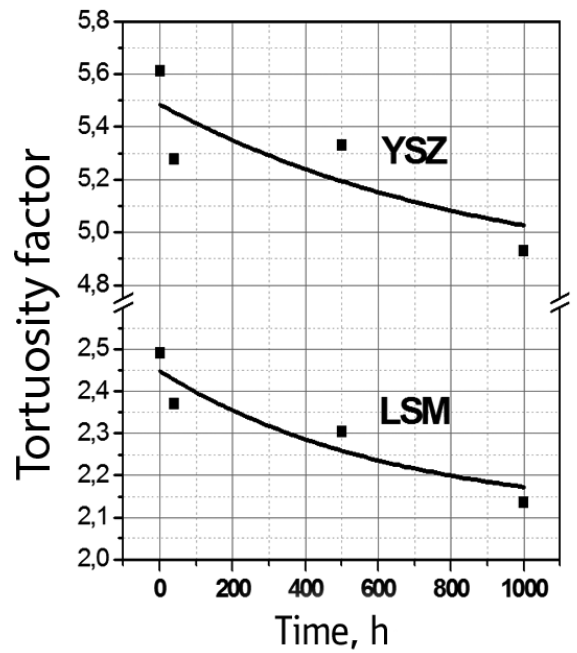

Fig. 9. The dependence of the tortuosity factor of cathode material LSM-YSZ from time, $T=800{ }^{\circ} \mathrm{C}, \mathrm{PO}_{2}=10^{-2} \mathrm{~atm}$

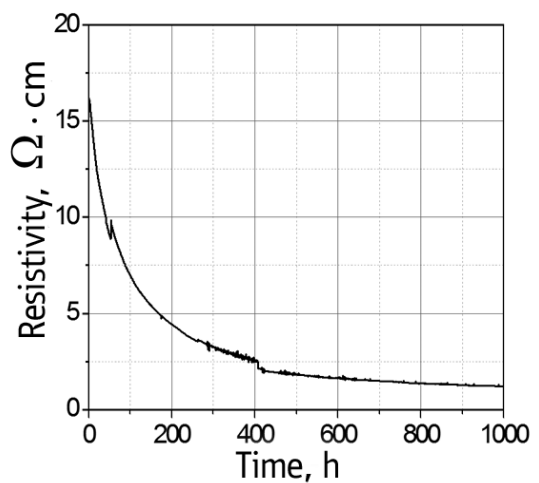

Fig. 10. The dependence of resistivity of the composite material LSM-YSZ from time, $T=800^{\circ} \mathrm{C}, \mathrm{PO}_{2}=10^{-2} \mathrm{~atm}$ 
degradation of materials, where the direct changes in the physical and chemical parameters are difficult, but it is possible to analyze the microstructure parameters. It is necessary for selection of the optimum conditions for the formation and operation of electrochemical devices such as: SOFC, electrochemical reformer, electrolysers, sensors etc.

\section{Acknowledgements}

The authors thank Porotnikova NM, Eremin VA, Medvedev DA, and Pankratal data, based on which the modeling was carried out. tov AA for prodviding us with experimen-

1. Porotnikova N. M. Isotopic exchange of oxygen and microstructure of materials on the basis of manganite of lanthanum-strontium and zirconium-itrium electrolyte. Ekaterinburg: 2013. 153 p. [Google Scholar].

2. Anan'ev M., Cavrilyuk A., Bronin D., Steinberger-Wilckens R., Mertens J. SOFC degradation quantification using image analysis. Proceedings of 15th European Fuel Cell Forum. Chapter 13 - Section B04. Lucerne, Switzerland: 28 June -1 July 2011:21-34. [Google Scholar].

3. Anan'ev M., Gavrilyuk A. Proceedings of 42-aya All Russian molodezhnaya school-conference «Modern problems of mathematics». Ekaterinburg, Russia. 30 January - 6 February 2011:276-279. [Google Scholar].

4. Janardhanan V., Heuveline V., Deutschmann O. Three-phase bound an length in solid oxide fuel cells: A Mathematical model. Journal of Power Sources 2008;178:368372. doi: 10.1016/j.jpowsour.2007.11.08. [Google Scholar].

5. Iwai H., Shikazono N., Matsui T., Teshima Hb., Kishimoto M., Kishida R., Hayashi D., Matsuzaki K., Kanno D., Saito M., Muroyama H., Eguchi K., Kasagi N., Yoshida H. Quantification of SOFC anode microstructure based on dual beam FIBSEM technique. Journal of Power Sources. 2010 ; 195:955-961. doi: 10.1016/j. jpowsour.2009.09.005. [Google Scholar].

6. Faes A., etc. // Fuel Cells. 2009; 6:841-851.

7. Faes A., Hessler-Wyser A., Presvytes D., Vayenas C.G., Vanherle J. Nickel-zirconia anode degradation and triple phase boundary quantification from microstructural analysis. Fuel Cells. 2009 ; 9(6):841-851. doi: 10.1002/fuce.200800147. [Google Scholar].

8. Farlenkov A. S., Anan'ev M. V. Probliemy Teoreticheskoi I Eksperimental'noi Khimii, XXIII Rossiiskaya Molodiezhnaya Nauchnaya Konferentsiya, Ekaterinburg, Russia, 23-26 April 2013:311-312. [Google Scholar]. 
А. С. Фарленков ${ }^{1,2}$, М. В. Ананьев ${ }^{1,2}$

${ }^{1}$ Уральский федеральный университет, 620002, Екатеринбург, Мира, 19. Факс: (343) 375-97-78; тел.: (343) 375-44-72; E-mail: rector@urfu.ru

${ }^{2}$ Институт высокотемпературной электрохимии УрО РАН, 620990, Екатеринбург, Академическая, 20. Факс: (343) 374-59-92; тел.: (343) 374-50-89; E-mail: Dir@ihte.uran.ru

\section{Моделирование микроструктуры и расчет фактора извилистости для катодных материалов LSM-YSZ*}

В работе на примере композиционного материала LSM-YSZ сравнивается изменение физико-химических свойств (скорости межфазного обмена кислорода и удельного сопротивления) и параметров микроструктуры (протяженности ТФГ и фактора извилистости) от времени с целью нахождения количественных взаимосвязей. Для электродных материалов LSM-YSZ проведена 3D-реконструкция микроструктуры и рассчитан фактор извилистости на основе результата анализа изображений РЭМ с использованием оригинального программного обеспечения.

* Работа выполнена при финансовой поддержке грантов РФФИ № 12-03-31847/12 и ФЦП № 20121.3.1-12-000-2006-004, соглашение № 8713 .

(C) Фарленков А. С., Ананьев М. В., 2015

\section{Введение}

Одним из важнейших направсохраняет способность генерировать лений развития мировой энергетики и энергосбережения является разработка и изучение твердооксидных топливных элементов (ТОТЭ), они относятся к классу химических источников тока, в которых химическая энергия реагентов (топлива и окислителя) электрохимическим способом преобразуется в электрическую. В роли окислителя обычно выступает кислород из воздуха, в роли топлива - водород. ТОТЭ электроэнергию все время, пока в него извне поступают реагенты, и отводятся продукты их взаимодействия.

Существенным преимуществом ТОТЭ является бесшумность работы и отстутствие вредных выбросов при их функционировании, но существует ряд проблем, связанных с деградацией материалов, из которых состоит ТОТЭ.

Известно, что микроструктура функциональных материалов являет- 
ся определяющим фактором кинетики процессов, протекающих при работе ТОТЭ. Источником информации о ней являются изображения, полученные методом растровой электронной микроскопии (РЭМ). Для оценки параметров микроструктуры, анализа двумерных микрофотографий сечений или поверхности исследуемого материала бывает недостаточно. Существует ряд параметров микроструктуры, которые можно рассчитать только из трехмерной модели: протяженность трехфазных (ТФГ) и межфазных (МФГ) гра- ниц; доля активных ТФГ, открытых пор; фактор извилистости и т. п.

В настоящей работе приводятся основные направления и результаты в области анализа параметров микроструктуры на примере композиционного материала LSM-YSZ, а также сравнивается изменение физико-химических свойств этого материала (скорости межфазного обмена кислорода и удельного сопротивления) и параметров его микроструктуры (протяженности ТФГ и фактора извилистости) от времени с целью нахождения количественных взаимосвязей.

\section{Результаты и обсуждение}

Изотопный обмен кислорода и микроструктура LSM-YSZ. В работе проводили испытания при $\mathrm{T}=850^{\circ} \mathrm{C}$, $\mathrm{PO}_{2}=10^{-2}$ атм двух симметричных ячеек. Первую симметричеую ячейку испытывали в течение 300 часов, другую - в течение 1000 часов. В процессе длительных испытаний методом изотопного обмена кислорода [1] исследовали кинетику взаимодействия кислорода газовой фазы с исследуемыми симметричными ячейками.

Параметры микроструктуры образцов до и после испытаний определяли с помощью цифровой обработки микрофотографий поперечных шлифов, полученных с помощью растрового электронного микроскопа Tescan MIRA $3 L M U$. На рис. 1 и на рис. 2 приведены микрофотографии структуры симметричной ячейки LSMYSZ | YSZ | LSM-YSZ $\left(\mathrm{La}_{0,8} \mathrm{Sr}_{0,2} \mathrm{MnO}_{3}-\right.$ $\left.0,82 \mathrm{ZrO}_{2} \cdot 0,08 \mathrm{Y}_{2} \mathrm{O}_{3}\right)$ до испытаний.

Поскольку контраст между фазами LSM и YSZ на изображении отсутствует (рис. 2), то был применен метод ана- лиза изображений [2], в ходе которого установлено, что функции распределения размеров зерен частиц различны, и эти изменения связаны с огрублением фазы LSM (рис. 3). По проведенной 3D-реконструкции микроструктуры электродов симметричных ячеек (рис. 4), получена зависимость ТФГ (контакт между LSM $\mid$ YSZ $\mid \mathrm{O}_{2}$ ) от времени.

Протяженность ТФГ определяли как отнесенное к объему количество соединений между вокселями (от англ. voxel $=$ volume pixel) трех типов, соответствующих фазам LSM, YSZ и порам $[4,5]$. Установлено, что протяженность ТФГ уменьшилась примерно на $15 \%$ (рис. 5), тогда как константа межфазного обмена кислорода $\mathrm{k}$ уменьшилась примерно на $16 \%$ в течение 1000 часов (рис. 6).

По-видимому, процесс межфазного обмена кислорода на ТФГ протекает достаточно быстро по сравнению с обменом кислорода на индивидуальных компонентах LSM и YSZ. В результате уменьшение протяженности ТФГ 


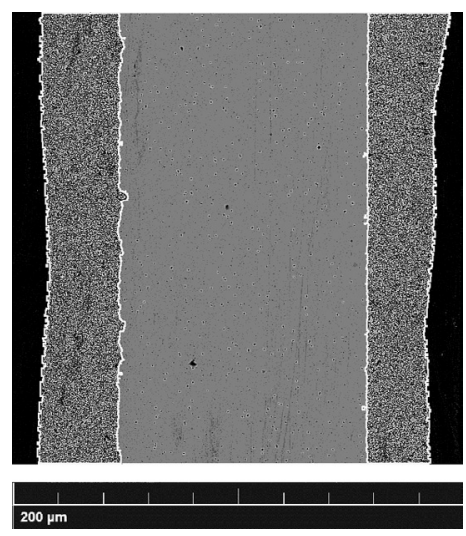

Рис. 1. Микрофотография сечения LSM-YSZ | YSZ | LSM-YSZ, толщина электролита $140 \pm 5$ мкм, электрода $41 \pm 10$ мкм

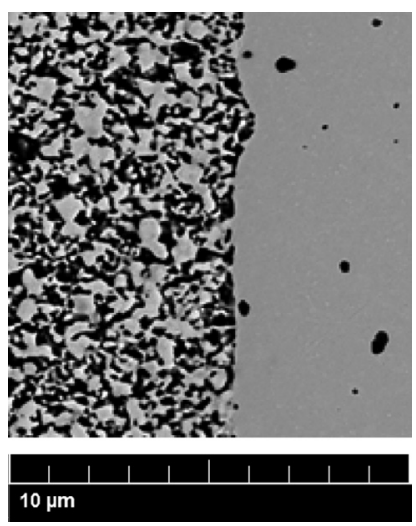

Рис. 2. Микрофотографии сечения ячейки LSM-YSZ | YSZ | LSM-YSZ

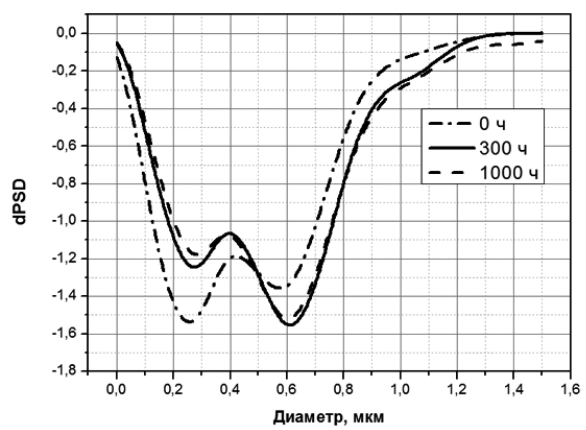

Рис. 3. Дифференциальные формы функций распределения размеров зерен фаз

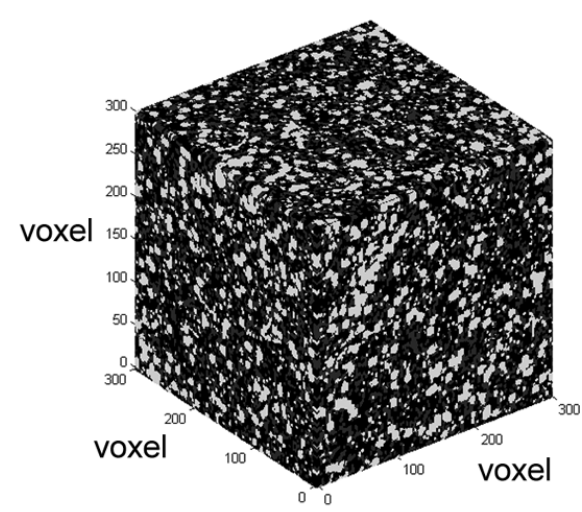

Рис. 4. 3D-реконструкция микроструктуры LSM-YSZ, серый - YSZ, белый - LSM, черный - поры; 1 мкм $=20$ вокселей

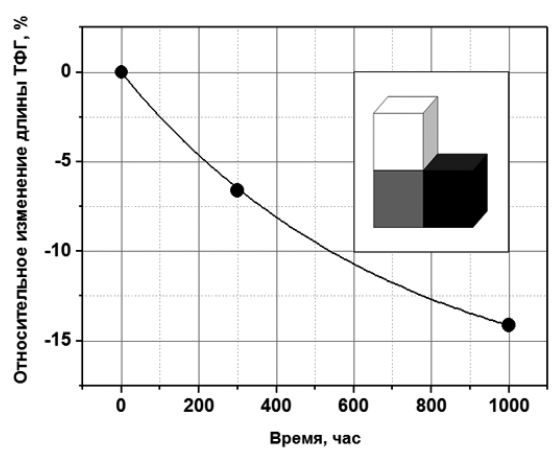

Рис. 5. Зависимость относительного изменения протяженности трехфазной границы от времени

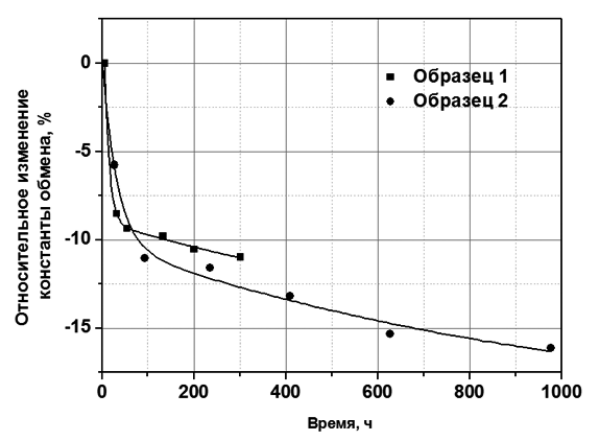

Рис. 6. Зависимость относительного изменения константы обмена от времени, $T=850^{\circ} \mathrm{C}, \mathrm{PO}_{2}=10^{-2} \mathrm{aTM}$ 
со временем приводит к уменьшению константы межфазного обмена кислорода композиционных катодных материалов LSM-YSZ [7].

Электропроводность и фактор извилистости композиционных материалов LSM-YSZ. Фактор извилистости статистически рассчитывается с помощью моделирования процесса случайного блуждания частиц методом Монте-Карло. В интересующем объеме генерируются блуждающие частицы в количестве $N$ штук. За один шаг работы программы каждая частица совершает $n$ блужданий с заданной длиной блуждания $L$. После этого рассчитывается сумма среднеквадратичных смещений всех частиц заданного ансамбля (1). Данная процедура повторяется требуемое количество раз [3]. Фактор извилистости определяется как отношение среднеквадратичного смещения частиц в свободном пространстве к среднеквадратичному смещению частиц в пористой среде (2) (рис. 7).

$$
\begin{gathered}
<r_{t}^{2}>=\frac{1}{n} \cdot \sum_{i=1}^{n}\left(\left\{x_{i}-x_{i}^{0}\right\}^{2}+\right. \\
\left.+\left\{y_{i}-y_{i}^{0}\right\}^{2}+\left\{z_{i}-z_{i}^{0}\right\}\right), \\
<\tau_{\varphi}>=\frac{\left\langle r_{t}^{2}>_{\text {free }}\right.}{\left\langle r_{t}^{2}\right\rangle_{\text {pore }}} .
\end{gathered}
$$

Здесь стоит также отметить, что величина фактора извилистости отличается от извилистости, которая определяется как отношение средней длины пор к толщине пористого материала. В отличие от интегральных характеристик микроструктуры, таких как пористость, доля фаз и их средний диаметр, величина фактора извилистости, в зависимости от того, для какой среды она считается, может быть пропорциональна физико-химическим величинам. В случае пор фактор извилистости пропорционален коэффициенту газопроницаемости; для кислород-ионного электролита - коэффициенту диффузии (ионной проводимости); для электронного проводника - удельной электропроводности материала [5]. К примеру, зависимость коэффициента диффузии и среднеквадратичного смещения от времени описывается выражением (3).

$$
D=\frac{1}{6} \cdot \frac{d}{d t}\left\langle r_{t}^{2}>.\right.
$$

В данной части работы на примере композиционного материала $\mathrm{La}_{0,6} \mathrm{Sr}_{0,4} \mathrm{MnO}_{3}-0,9 \mathrm{ZrO}_{2} \cdot 0,1 \mathrm{Y}_{2} \mathrm{O}_{3}$ показано, что в течение 1000 часов при $T=800^{\circ} \mathrm{C}, \mathrm{PO}_{2}=10^{-2}$ атм удельное сопротивление уменьшается в пределах порядка (рис. 10). Во время испытаний извлекались образцы-свидетели после 40, 500 и 1000 часов выдержки.

На основе результатов сегментации изображений РЭМ (рис. 8) для сечений образцов до и после испытаний с помощью разработанного оригинального программного обеспечения рассчитаны факторы извилистости, как для пористой структуры, так и для фаз LSM и YSZ (рис. 9).

Обнаружено уменьшение факторов извилистости фаз LSM и YSZ, что коррелирует с падением удельного сопротивления исследуемого композиционного материала (рис. 9, 10). Для пористой структуры монотонной зависимости обнаружить не удалось. Анализ изображений показал, что в результате выдержки происходит диф- 
фузионное распространение фаз LSM и YSZ, приводящее к укрупнению ча-

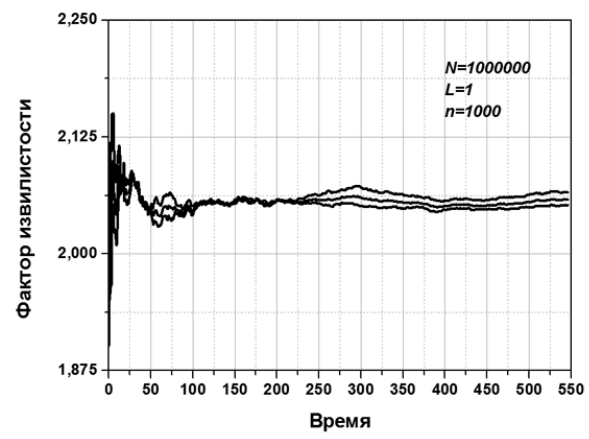

Рис. 7. Эволюция значений фактора извилистости в зависимости от шага работы алгоритма

LSM-YSZ до испытаний

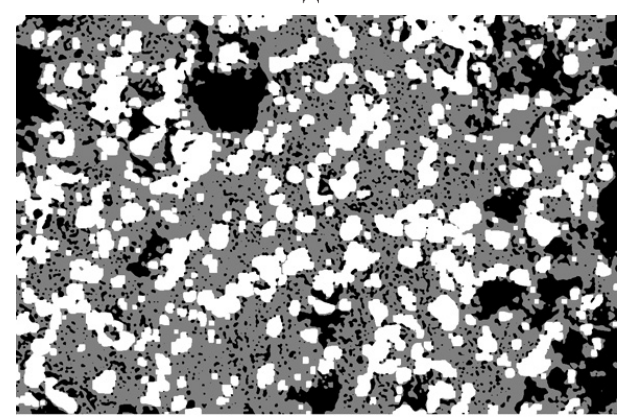

$5 \mu \mathrm{m}$

LSM-YSZ после выдержки в течение 1000 часов при $T=800{ }^{\circ} \mathrm{C}$ и $\mathrm{PO}_{2}=10^{-2}$ атм

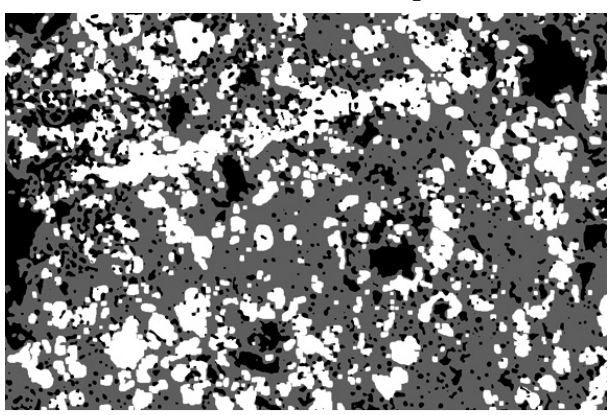

\section{$5 \mu \mathrm{m}$}

Рис. 8. Результат обработки микрофотографии сечения композиционного материала LSM-YSZ, SEM (серый цвет - YSZ, белый цвет LSM, черный цвет - поры) стиц при неизменных линейных размерах самого образца. Процесс диффузионного роста фазы YSZ протекает быстрее по сравнению с LSM, по-видимому, из-за того, что изначально YSZ взят в форме нанопорошка (рис. 8). Образование более связной структуры фаз, входящих в состав композиционного материала, служит причиной снижения сопротивления (рис. 10).

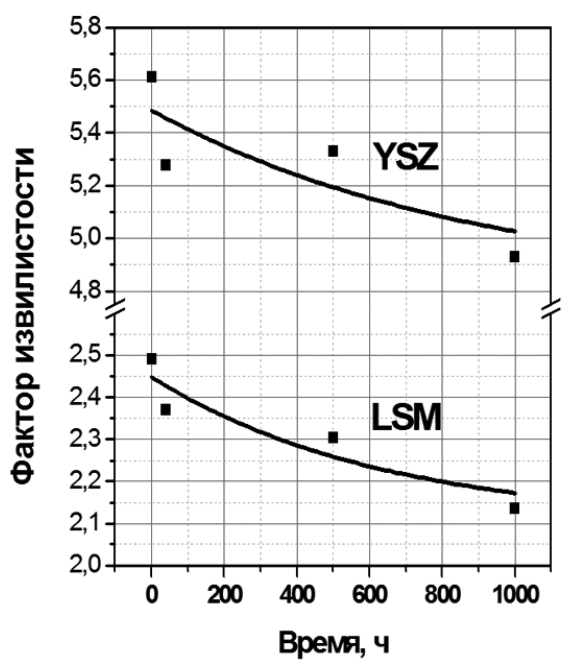

Рис. 9. Зависимость фактора извилистости катодного материала LSM-YSZ от времени, $T=800^{\circ} \mathrm{C}, \mathrm{PO}_{2}=10^{-2}$ атм

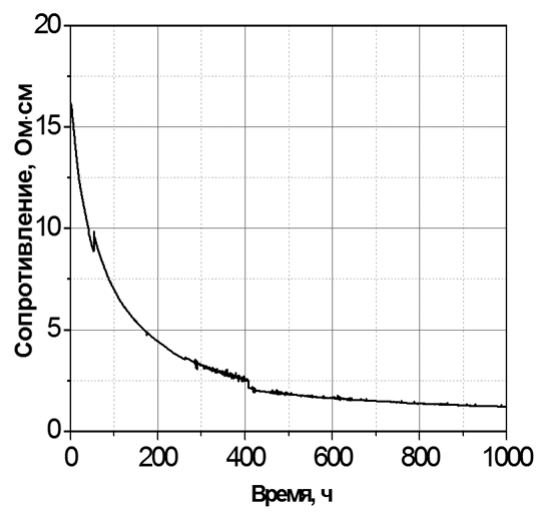

Рис. 10. Зависимость удельного сопротивления композиционного материала LSM-YSZ от времени, $T=800{ }^{\circ} \mathrm{C}, \mathrm{PO}_{2}=10^{-2} \mathrm{aTM}$ 
Длительная выдержка в условиях эксперимента приводит к улучшению контакта между зернами компонентов, входящих в состав композиционного материала. Количественным параметром, характеризующим процесс диффузного распростронения фаз LSM и YSZ, является фактор извилистости.

\section{Выводы}

В ходе работы проведена 3D-peконструкция микроструктуры на основе анализа и обработки изображений РЭМ, рассчитана протяженность ТФГ и МФГ, определены доли активных ТФГ и открытых пор.

Для симметричных ячеек $\left(\mathrm{La}_{0,8} \mathrm{Sr}_{0,2} \mathrm{MnO}_{3}-0,82 \mathrm{ZrO}_{2} \cdot 0,08 \mathrm{Y}_{2} \mathrm{O}_{3}\right)$ получена взаимосвязь между константой межфазного обмена кислорода и протяженностью ТФГ. Для композиционного материала $\left(\mathrm{La}_{0,6} \mathrm{Sr}_{0,4} \mathrm{MnO}_{3}-\right.$ $0,9 \mathrm{ZrO}_{2} \cdot 0,1 \mathrm{Y}_{2} \mathrm{O}_{3}$ ) найдена корреляция между факторами извилистости фаз
LSM и YSZ и удельным сопротивлением.

Подход, использованный в данной работе, может быть полезным при исследовании процессов деградации электрохимических материалов, где прямое изменение физико-химических параметров затруднено, но возможен анализ параметров микроструктуры. Это необходимо для выбора оптимальных условий формирования и эксплуатации электрохимических устройств, таких как ТОТЭ, электрохимические риформеры, электролизеры, сенсоры и др.

\section{Благодарности}

Авторы выражают благодарность за предоставление экспериментальных Поротниковой Н. М., Ерёмину В. А., данных, на основе которых проводиМедведеву Д. А. и Панкратову А. А. лось моделирование.

\section{1. Поротникова Н. М. // Изотопный обмен кислорода и микроструктуры материа-} лов на основе манганитов лантана-стронция и цирконий-итриевого электролита. Екатеринбург, 2013. 153 с.

2. Ananev M. V., GavrilyukA. L., Bronin D. I., Steinberger-Wilckens R., Mertens J. SOFC degradation quantification using image analysis // Proceedings of 15th European Fuel Cell Forum. Chapter 13 - Section B04. Lucerne, Switzerland, 28 June - 1 July 2011. P. 21-34.

3. Ананьев М. В., Гаврилюк А. Л. // 42-я Всероссийская молодежная школа-конференция «Современные проблемы математики». Екатеринбург, Россия, 30 января - 6 февраля 2011. С. 276-279.

4. Janardhanan V. M., etc. // Journal of PowerSources. 2008. № 178. P. 368-372.

5. Iwai H. etc. // Journal of Power Sources. 2010. № 195. P. 955-961.

6. Faes A. etc. // Fuel Cells. 2009. № 6. P. 841-851.

7. Фарленков А. С., Ананьев М. В. // Проблемы теоретической и экспериментальной химии / XXIII Российская молодежная научная конференция. Екатеринбург, Россия, 23-26 апреля 2013. С. 311-312. 